\title{
STUDI TENTANG IKLIM ORGANISASI DAN ORGANIZATIONAL CITIZENSHIP BEHAVIOR PADA KSP BINA SEJAHTERA
}

\author{
WANDA ANGELIKA \\ SYAHIR NATSIR \\ YOBERTH KORNELIUS \\ PROGRAM STUDI S1, MANAJEMEN, FAKULTAS EKONOMI, UNIVERSITAS TADULAKO \\ Email: wirawanwanda.ww@gmail.com, syahir.natsir@yahoo.com,yoberthkornelius@yahoo.com
}

\begin{abstract}
This study aims to find out how the organizational climate and the implementation of Organizational Citizenship Behavior (OCB), as well as the factors that influence both aspects of the KSP Bina Sejahtera. This research is a type of qualitative research that is descriptive. Data sources come from observation and in-depth interviews. The data analysis technique used is interactive analysis of Milles and Hubberman, where data is collected, presented, reduced, and drawn conclusions. The results show that a good organizational climate and the application of Organizational Citizenship Behavior (OCB) are very important for the progress of an organization because it has influence on increasing maximum performance. In addition, the organizational climate influences the creation of $O C B$ actions carried out by employees, because the organizational climate is an initial condition that triggers $O C B$. When the organizational climate is good, the members of the organization will always support the work beyond the obligations they should and will always support the goals of the organization.
\end{abstract}

Keywords: Organizational Climate, Organizational Citizenship Behavior (OCB)

Penelitian ini bertujuan untuk mengetahui bagaimana iklim organisasi dan penerapan Organizational Citizenship Behavior (OCB), serta faktor-faktor yang mempengaruhi kedua aspek tersebut pada KSP Bina Sejahtera. Penelitian ini merupakan jenis penelitian kualitatif yang bersifat deskriptif. Sumber data berasal dari observasi dan wawancara mendalam (in-depth interview). Teknik analisis data yang digunakan adalah analisis interaktif Milles dan Hubberman, dimana data dikumpul, disajikan, direduksi, dan ditarik kesimpulan.Hasil penelitian menunjukkan bahwa bahwa iklim organisasi yang baik dan adanya penerapan Organizational Citizenship Behavior (OCB) sangatlah penting bagi kemajuan sebuah organisasi karena memiliki pengaruh terhadap peningkatan kinerja yang maksimal. Selain itu, iklim organisasi mempengaruhi terciptanya tindakan OCB yang dilakukan oleh karyawan, karena iklim organisasi merupakan kondisi awal yang memicu terjadinya OCB. Ketika iklim organisasi baik maka anggota organisasi akan selalu mendukung pekerjaan melebihi kewajiban seharusnya dan akan selalu mendukung tujuan organisasi.

Kata Kunci: Iklim Organisasi, Organizational Citizenship Behavior (OCB)

\section{PENDAHULUAN}

Kunci keberhasilan organisasi adalah kinerja maksimal, dimana anggota organisasi dapat memberikan kontribusi positif pada perencanaan dan juga implementasi tugas-tugas dalam pencapaian tujuan organisasi. Kinerja anggota organisasi baik secara individu maupun kelompok dinilai melalui perilaku dan juga hasil kerja. Perilaku merupakan aspek dalam penilaian kinerja yang dapat secara nyata terlihat pada setiap anggota organisasi.

Perilaku organisasi bukan hanya merupakan pembelajaran tentang tindakan dalam organisasi, namun adalah penerapan dari pengetahuan tentang tindakan dalam organisasi. Kinerja anggota organisasi dapat dinilai melalui perilaku anggota organisasi sebagaimana ia bertindak dan 
melaksanakan tanggung jawabnya untuk mencapai tujuan dari organisasi. Dibutuhkan bukan hanya sekedar kinerja biasa untuk mencapai tujuan, melainkan kinerja maksimal yang memberi dampak bagi kemajuan organisasi.

Kinerja maksimal merupakan tuntutan organisasi yang ditunjukkan tidak hanya dengan perilaku inrole tapi juga extra-role yang disebut juga sebagai Organizational Citizenship Behavior (OCB). Organizational Citizenship Behavior (OCB) merupakan perilaku individual yang bersifat "discretionary" yang tidak secara langsung diakui oleh sistem reward formal dan secara bersamasama akan mendorong fungsi organisasi lebih efektif (Organ,1990). Maka penerapan OCB dapat mendorong terciptanya kinerja maksimal dalam organisasi.

Selain OCB, hal lain yang juga menjadi pendorong terciptanya kinerja yang maksimal adalah iklim organisasi. Iklim organisasi dan OCB saling berhubungan dan mempengaruhi dalam penciptaan kinerja yang maksimal. Koperasi merupakan organisasi yang berazaskan kekeluargaan, sehingga dapat terlihat secara jelas bagaimana hubungan serta kerja sama antar individu didalamnya.Adapun tujuan yang ingin dicapai dalam penelitian ini adalah untuk mengetahui bagaimana iklim organisasi dan penerapan Organizational Citizenship Behavior (OCB) ), serta apa saja faktor-faktor yang mempergaruhi kedua aspek tersebut pada KSP Bina Sejahtera.

\section{KAJIAN LITERATUR}

Davis dan Newstorm (2002) menyatakan bahwa "Iklim organisasi merupakan sebuah konsep yang menggambarkan suasana internal lingkungan organisasi yang dirasakan oleh anggotanya selama beraktivitas dalam rangka tercapainya tujuan organisasi”. Iklim tidak dapat dilihat dan disentuh, tapi iklim ada dan dapat dirasakan. Iklim dipengaruhi oleh hampir semua hal yang terjadi dalam suatu organisasi. Jika sebuah organisasi ingin berhasil dalam mewujudkan cita-cita dan tujuannya secara utuh dan sempurna, maka dibutuhkan individu-individu yang handal sebagai sumber daya yang akan memegang kendali tali organisasi. Agar Sumber Daya Manusia di dalam organisasi dapat bekerja secara optimal dan memiliki loyalitas yang tinggi, maka organisasi harus dapat menciptakan iklim yang baik dan menyenangkan. Sehingga Sumber Daya Manusia yang telah terbentuk kualitasnya dapat terus dipertahankan dan mereka memiliki prestasi kerja yang tinggi.

Iklim organisasi dapat dilukiskan dan diukur. Sebagaimana Robert Stringer (dalam Wirawan, 2007:131-133) berpendapat bahwa karakteristik atau dimensi iklim organisasi mempengaruhi motivasi anggota organisasi untuk berperilaku tertentu. Ia mengatakan bahwa untuk mengukur iklim organisasi terdapat enam dimensi yang diperlukan, yaitu sebagai berikut :

1. Struktur

Struktur organisasi merefleksikan perasaan dalam organisasi secara baik dan mempunyai peran dan tanggung jawab yang jelas dalam lingkungan organisasi. Struktur tinggi jika anggota organisasi merasa pekerjaan mereka didefenisikan secara baik. Struktur rendah jika mereka merasa tidak ada kejelasan mengenai siapa yang melakukan tugas dan mempunyai kewenangan mengambil keputusan.

2. Standar-standar

Standar-standar dalam suatu organisasi mengukur perasaan tekanan untuk meningkatkan kinerja dan derajat kebanggaan yang dimiliki oleh anggota organisasi dalam melakukan pekerjaan dengan baik. Standar-standar tinggi artinya anggota organisasi selalu berupaya mencari jalan untuk meningkatkan kinerja. Standar-standar rendah merefleksikan harapan yang lebih rendah untuk kinerja. 3. Tanggung jawab

Tanggung jawab merefleksikan perasaan karyawan bahwa mereka menjadi "bos diri sendiri" dan tidak memerlukan keputusannya dilegitimasi oleh anggota organisasi lainnya. Tanggung jawab tinggi menunjukkan bahwa anggota organisasi merasa didorong untuk memecahkan problemnya sendiri. Tanggung jawab rendah menunjukkan bahwa pengambilan resiko dan percobaan terhadap pendekatan baru tidak diharapkan.

4. Penghargaan

Penghargaan mengindikasikan bahwa anggota organisasi merasa dihargai jika mereka dapat menyelesaikan tugas secara baik. Penghargaan merupakan ukuran penghargaan dihadapkan dengan kritik dan hukuman atas penyelesaian pekerjaan. Iklim organisasi yang menghargai kinerja 
berkarakteristik keseimbangan antara imbalan dan kritik. Penghargaan rendah artinya penyelesaian pekerjaan dengan baik diberi imbalan secara tidak konsisten.

\section{Dukungan}

Dukungan merefleksikan perasaan percaya dan saling mendukung yang terus berlangsung di antara anggota kelompok kerja. Dukungan tinggi jika anggota organisasi merasa bahwa mereka bagian tim yang berfungsi dengan baik dan merasa memperoleh bantuan dari atasannya, jika mengalami kesulitan dalam menjalankan tugas. Jika dukungan rendah, anggota organisasi merasa terisolasiatau tersisih sendiri.

6. Komitmen

Komitmen merefleksikan perasaan bangga anggota terhadap organisasinya dan derajat kesetiaan terhadap pencapaian tujuan organisasi. Perasaan komitmen kuat berisolasi dengan kesetiaan personal. Level rendah komitmen artinya karyawan merasa apatis terhadap organisasi dan tujuannya.

Terdapat lima faktor yang mempengaruhi terjadinya iklim suatu organisasi sebagaimana yang dikemukakan Robert Stringer (dalam Wirawan, 2002), yaitu lingkungan eksternal, strategi, praktik kepemimpinan, pengaturan organisasi, dan sejarah organisasi.

1. Lingkungan Eksternal

Industri atau bisnis yang sama mempunyai iklim organisasi umum yang sama. Misalnya, iklim organisasi umum perusahaan asuransi umumnya sama, demikian juga dengan iklim organisasi pemerintah, sekolah dasar, atau perusahaan industri minyak kelapa sawit di Indonesia, mempunyai iklim umum yang sama. Kesamaan faktor umum tersebut disebabkan pengaruh lingkungan eksternal organisasi.

\section{Strategi Organisasi}

Kinerja suatu perusahaan bergantung pada strategi (apa yang diupayakan untuk dilakukan), energi yang dimiliki oleh karyawan untuk melaksanakan pekerjaan yang diperlukan adalah strategi, dan faktor-faktor lingkungan penentu dari level energi tersebut. Strategi yang berbeda menimbulkan pola iklim organisasi yang berbeda. Strategi mempengaruhi iklim organisasi secara tidak langsung.

\section{Pengaturan organisasi}

Pengaturan organisasi mempunyai pengaruh paling kuat terhadap iklim organisasi. Sebuah penelitian menunjukkan bahwa ada banyak sekolah menengah di Amerika Serikat yang menjadi contoh baik bagaimana pengaturan organisasi menentukan iklim organisasi. Pengaturan terkait dengan struktu dalam organisasi, yaitu bagaiman pengertian dan penerapan terkait tugas dan tanggung jawab masing-masing jabatan.

\section{Kekuatan Sejarah}

Semakin tua umur suatu organisasi semakin kuat pengaruh kekuatan sejarahnya. Pengaruh tersebut dalam bentuk tradisi dan ingatan yang membentuk harapan anggota organisasi dan mempunyai pengaruh terhadap iklim organisasinya. Sejarah dapat mempengaruhi bagaimana pencapaian dan peningkatan pada organisasi, dengan tolak ukur kinerja terdahulu.

\section{Kepemimpinan}

Perilaku pemimpin mempengaruhi iklim organisasi yang kemudian mendorong motivasi karyawan. Pemimpin yang supportive dapat memberi dorongan yang sangat besar bagi tiap karyawan, terkait perlakuan yang diterima, yang dapat memotivasi karyawan untuk bekerja lebih baik. Motivasi karyawan merupakan pendorong utama terjadinya kinerja.

Robbins (2006:31) mendefinisikan organizational citizenship behavior sebagai perilaku pilihan yang tidak menjadi bagian dari kewajiban kerja formal seorang karyawan, namun mendukung berfungsinya organisasi tersebut secara efektif. Ada beberapa pokok pikiran penting mengenai organizational citizenship behavior, yaitu; (a) tindakan bebas, spontan, sukarela yang dilakukan demi kepentingan pihak lain (rekan kerja, kelompok, atau organisasi); (b) tidak diperintahkan secara formal; (c) tidak diakui dengan kompensasi atau penghargaan formal. Oleh karena itu, dapat disimpulkan bahwa organizational citizenship behavior adalah kontribusi karyawan di luar dari deskripsi kerja formal, yang dilakukan secara sukarela, spontan, dan tidak diakui oleh sistem reward, namun memberikan kontribusi pada efektivitas dan efisiensi fungsi organisasi. 
OCB dibangun dari lima dimensi yang masing-masing bersifat unik, yaitu altruism (perilaku menolong), conscientiousness (kepatuhan), sportmanship (sportifitas), courtesy (kesopanan), dan civic virtue (tanggung jawab sebagai anggota organisasi). Kelima dimensi tersebut dapat dijabarkan sebagai berikut:

\section{Altruism}

Perilaku karyawan dalam menolong rekan kerjanya yang mengalami kesulitan dalam situasi yang sedang dihadapi baik mengenai tugas dalam organisasi maupun masalah pribadi orang lain. Dimensi ini mengarah kepada memberi pertolongan yang bukan merupakan kewajiban yang ditanggungnya. Refleks menolong akan muncul apabila individu yang altruistif melihat seseorang yang perlu untuk dibantu, seperti orang yang sudah dikenalnya ataupun orang asing yang belum dikenal (stranger). Ciriciri lain dari perilaku ini adalah "only in one-shot episode" yang berarti bahwa ketika seseorang melakukan tindakan altruism pada beberapa orang, tindakan altruism tersebut tidak berhubungan dengan tindakan altruism-nya yang lain, karena individu yang altruistif tersebut memang tidak mengharapkan ada imbalan dari tindakannya tersebut di masa depan.

\section{Conscientiousness}

Conscientiousness mengacu pada sikap lebih berhati-hati dan mendengarkan kata hati. Big Five Teori memaparkan individu yang mempunyai skor tinggi pada traits conscientiousness memiliki kontrol diri yang bagus, terorganisir, memprioritaskan tugas, mengikuti norma dan peraturan, dan lain sebagainya. Adanya perilaku tersebut dapat mengindikasikan bahwa para pekerja telah menerima dan mematuhi aturan dan prosedur yang ada di dalam perusahaan. Jadi bila ditinjau dalam konteks sebuah perusahaan adanya perilaku ini tentunya akan sangat menguntungkan, karena pekerja dengan conscientiousness yang tinggi akan memiliki sikap yang bagus daripada rekan-rekan kerjanya yang lain dengan menunjukkan ketaatan pada regulasi dan prosedur perusahaan yang lebih baik.

\section{Sportmanship}

Dimensi sportsmanship dapat dilihat dari aspek toleransi dan keluhan (complain) individu dalam pekerjaannya. Individu dengan sikap sportsmanship yang tinggi akan sangat memperhatikan hal-hal detail dalam pekerjaannya, dapat secara fair menjalankan pekerjaanya dan sedikit mengeluh, dan kemampuan beradaptasi yang tinggi dengan situasi dan lingkungan kerjanya. Pada konteks sebuah perusahaan sikap ini tentunya akan sangat menguntungkan, karena para pekerja akan dengan mudah beradaptasi dengan perubahan yang ada di perusahaanya, sebagai contoh apabila perusahaan mengeluarkan kebijakan baru mengenai suatu hal, pekerja yang memiliki sikap sportsmanship tinggi akan dengan mudah menerima kebijakan baru itu dan mengesampingkan masalah-masalah kecil yang mungkin muncul disebabkan oleh kebijakan baru tersebut.

\section{Courtessy}

Dimensi courtesy dapat digambarkan dengan sebuah bentuk tindakan yang bertujuan untuk mencegah munculnya masalah, sedangkan secara arti kata courtesy dapat diartikan dengan sikap sopan, dan mempertimbangkan orang lain. Tindakan Courtesy dapat dicontohkan dengan menawari teman kerja untuk makan bersama, apabila sedang memiliki tugas yang sama selalu mengingatkan teman kerjanya agar tidak lupa atau mungkin menawarinya untuk saling sharing dan bertukar pikiran menyelesaikan tugas tersebut, dan lain sebagainya.

\section{Civic Virtue}

Perilaku yang mengindikasikan tanggung jawab pada kehidupan organisasi (mengikuti perubahan dalam organisasi, mengambil inisiatif untuk merekomendasikan bagaimana operasi atau prosedur prosedur organisasi dapat diperbaiki, dan melindungi sumber-sumber yang dimiliki oleh organisasi). Dimensi ini mengarah pada tanggung jawab yang diberikan organisasi kepada seorang untuk meningkatkan kualitas bidang pekerjaan yang ditekuni. Faktor-faktor yang dapat mendukung timbulnya OCB adalah: pemimpin; karakteristik tugas; karakteristik kelompok; karakteristik organisasional; dan konteks kultural.

1. Pemimpin

Tipe pemimpin bisa menjadi faktor pemicu munculnya OCB, seperti pemimpin dengan tipe supportive yang dapat membuat karyawannya merasa diperhatikan kesejahteraannya, sehingga karyawan bersedia melakukan timbal balik kepada pimpinannya. Selain itu juga ada pemimpin 
instrumental yang dapat sangat membantu karyawan untuk menghindari ketidakjelasan tugas yang ada dalam pekerjaan, dan hal ini bisa menjadi penyebab seorang karyawan menyukai pimpinannya dan mau membantu pimpinannya semampu karyawan tersebut. Disisi lain, pemimpin dengan tipe transformasional yang dapat menyelaraskan nilai-nilai, visi, dan tujuan karyawan dan perusahaan, akan bisa memunculkan performa karyawan diluar ekspektasi perusahaan bukan hanya sekedar karena mereka ingin dihargai karena usahanya, namun karena mereka merasa bahwa misi dan tujuan mereka searah dengan yang dimiliki perusahaan. Pemimpin yang instrumental, transformasinal dan supportive dapat mempengaruhi OCB karena dampaknya akan dirasakan oleh karyawan sebagai perilaku membantu pemimpin sehingga karyawan akan merasa berkewajiban untuk membalas.

2. Karakteristik Tugas

Karakteristik tugas adalah sifat dari tugas yang terkandung dalam suatu pekerjaan, meliputi berbagai dimensi yang dapat mendorong keefektifan individu dalam bekerja. Beberapa karakteristik tugas yang mempengaruhi karyawan untuk menampilkan organizational citizenship behavior antara lain otonomi tugas, identitas tugas, variasi tugas, signifikansi tugas (makna atau pentingnya tugas), saling ketergantungan tugas (task interdependence), serta umpan balik tugas.

3 Karakteristik Kelompok

Karakteristik kelompok yang mempengaruhi organizational citizenship behavior meliputi kohesivitas kelompok, kualitas hubungan antara anggota pada kelompok kerja, potensi atau kemampuan kelompok, serta dukungan tim yang dirasakan karyawan.

4. Karakteristik Organisasional

Karakteristik organisasional yang dapat menjadi faktor terjadinya Organizational citizenship behavior adalah formalisasi dan kekakuan organisasi, dukungan organisasi yang dipersepsikan karyawan, jarak antara karyawan dan supervisor, dan hambatan-hambatan dalam organisasi.

5. Konteks Kultural

Kebudayaan bangsa dapat berpengaruh pada kondisi yang berkaitan dengan terciptanya organizational citizenship behavior. Dua dimensi kebudayaan yang mempengaruhi persepsi dan ekspresi terhadap organizational citizenship behavior adalah individualisme dan kolektivisme, serta jarak kekuasaan.

\section{METODE PENELITIAN}

Jenis penelitian yang digunakan dalam penelitian ini adalah penelitian kualitatif, yang menekankan keadaan sebenarnya dari suatu objek yang berhubungan langsung dengan konteks yang menjadi perhatian peneliti. Pendekatan kualitatif memiliki beberapa karakteristik. Iskandar (2009:47) menyimpulkan bahwa terdapat tujuh karakteristik penelitian kualitatif yang juga sebagaimana merupakan karakteristik dalam penelitian ini, yaitu:

1. Bersifat induktif, yaitu: berpikir dari yang khusus menuju kesimpulan yang bersifat umum.

2. Melihat setting penelitian, yaitu: mempelajari manusia dalam konteks dimana mereka hidup. Sebagaimana dalam penelitian ini dilakukan pada karyawan KSP Bina Sejahtera ditempat mereka bekerja, diteliti dalam konteks dimana mereka bekerja.

3. Memahami manusia dari sudut pandang mereka sendiri. Padapenelitian ini, dilakukan wawancara secara mendalam, dengan memberi pertanyaan sesuai aspek dan teliti, dan memberikan kesempatan kepada informan untuk dapat mengutarakan pendapat mereka secara bebas dan terbuka.

4. Mementingkan proses dari pada hasil penelitian. Pada penelitian kualitatif ini proses saat penelitian sangatlah penting, termasuk didalamnya interaksi serta pandangan informan saat proses penelitian berlangsung.

5. Menekankan pada keabsahan data. Pada penelitian ini, untuk mendapatkan data yang akurat, setelah melakukan observasi dan in-depth interview, juga dilakukan member check yaitu proses pengecekan data yang diperoleh, apabila hasilnya disepakati oleh pemberi data maka data tersebut valid.

6. Bersifat humanities, yaitu: menuntut keterlibatan langsung peneliti dalam pencarian data. Adanya observasi tahap awal, dan observasi lanjutan, serta interaksi bersama karyawan juga adanya wawancara mendalam dalam penelitian ini dilakukan sebagai terapan terkait dengan keterlibatan langsung antara peneliti dengan karyawan KSP Bina Sejahtera. 
7. Seluruh kehidupan manusia dianggap bermakna dan berharga. Untuk itu pada penelitian ini, semua aspek dalam KSP Bina Sejahtera yang dilihat, didengarkan, maupun dirasakan semuanya merupakan lingkup kehidupan karyawan sebagai manusia yang bermakna dan berharga, sehingga dalam proses penelitian, tidak dilakukan adanya penambahan maupun pengurangan data yang diperoleh dari hasil pengamatan maupun wawancara.

Teknik pengumpulan data yang digunakan dalam penelitian ini adalah sebagai berikut:

1. Observasi

Observasi dapat diartikan sebagai kegiatan mengamati secara langsung tanpa mediator suatu objek untuk melihat dengan dekat kegiatan yang dilakukan objek tersebut. Observasi berguna untuk menjelaskan, memberikan dan merinci gejala yang terjadi, mengamati secara langsung objek yang diteliti sehingga memperoleh data yang diperlukan.

\section{In-depth Interview}

Penelitian ini juga menggunakan teknik wawancara secara mendalam (in-depth interview) untuk mengadakan komunikasi secara verbal dengan subjek penelitian. In-depth Interview adalah proses memperoleh keterangan untuk tujuan penelitian dengan cara tanya jawab sambil bertatap muka antara pewawancara dengan responden atau orang yang diwawancarai, dengan atau tanpa menggunakan pedoman (guide) wawancara dimana pewawancara dan informan terlibat dalam kehidupan sosial yang relatif lama (Sutopo 2006: 72).

3. Dokumentasi

Dokumentasi yaitu teknik penggumpulan data yang digunakan untuk mendapatkan data mengenai iklim organisasi dan penerapan Organizational Citizenship Behavior (OCB) pada KSP Bina Sejahtera. Dokumentasi dilakukan guna untuk mendapatkan gambaran KSP Bina Sejahtera mengenai iklim organisasi dan penerapan OCB. Subjek penelitian ini yaitu karyawan KSP Bina Sejahtera yang jumlah keseluruhan karyawannya yaitu sepuluh (10) orang.

Tabel 1. Jumlah Keseluruhan Karyawan KSP Bina Sejahtera

\begin{tabular}{|c|l|c|}
\hline No. & \multicolumn{1}{|c|}{ JABATAN } & JUMLAH \\
\hline 1 & Pimpinan & 1 \\
\hline 2 & Account Officer (AO) & $\mathbf{5}$ \\
\hline 3 & Keuangan & 1 \\
\hline 4 & Kasir & $\mathbf{1}$ \\
\hline 5 & Administrasi Berkas & $\mathbf{1}$ \\
\hline 6 & Administrasi Kredit & $\mathbf{1 0}$ \\
\hline \multicolumn{2}{|c|}{ JUMLAH } & $\mathbf{y}$ \\
\hline
\end{tabular}

Pemilihan informan dalam penelitian ini menggunakan Purposive Sampling. Sugiyono dalam Agus (2016), menyatakan Purposive Sampling adalah teknik penentuan sampel dengan pertimbangan tertentu. Jadi, informan dalam penelitian ini dipilih secara sengaja karena di anggap memiliki informasi pengetahuan yang dibutuhkan penelitian ini, juga dengan pertimbangan masa kerja dari yang terlama hingga yang terbaru untuk mendapatkan informasi yang lebih akurat. Jadi, informan yang diambil dalam penelitian ini berjumlah 5 orang, dengan rincian sebagai berikut:

Tabel 2. Daftar Informan

\begin{tabular}{|c|l|c|}
\hline No. & \multicolumn{1}{|c|}{ JABATAN } & MASA KERJA \\
\hline 1 & Kepala Cabang KSP Bina Sejahera Palu & 18 Tahun \\
\hline 2 & Keuangan & 18 Tahun \\
\hline 3 & Koordinator Bagian Account Officer (AO) & Tahun \\
\hline 4 & Account Officer (AO) & Tahun \\
\hline 5 & Account Officer (AO) & Tahun \\
\hline
\end{tabular}

Banyak hasil penelitian kualitatif diragukan kebenarannya karena beberapa hal, yaitu subjuktivitas peneliti merupakan hal yang dominan dalam penelitian kualitatif, alat penelitian yang diandalkan adalah wawancara dan observasi mengandung banyak kelemahan ketika dilakukan secara terbuka dan 
apalagi tanpa kontrol, dan sumber data kualitatif yang kurang credible akan mempengaruhi hasil akurasi penelitian. Oleh karena itu, di butuhkan beberapa cara menentukan keabsahan data, yaitu : derajat kepercayaan (credibility), keteralihan (transferability), ketergantungan (dependability), dan kepastian (confirmability) (Moleong, 2007). Pada pengujian keabsahan data penelitian ini, peneliti menggunakan uji kredibilitas dengan teknik tringulasi dan member check.

Tringulation is qualitative cross-validation. It assesses the sufficiency of the data according to the covergence of multiple data sources or multiple data collection procedurs (Wiliam Wiersma dalam Sugiyono 2012). Tringulasi yang digunakan pada penelitian ini yaitu Tringulasi Teknik. Tringulasi teknik untuk menguji kredibilitas data dilakukan dengan cara mngecek data kepada sumber yang sama dengan teknik yang berbeda. Misalnya pada data yang diperoleh dengan wawancara, lalu dicek dengan observasi, menghasilkan data yang berbeda, maka peneliti melakukan diskusi lebih lanjut kepada sumber data yang bersangkutan atau yang lain, untuk memastikan data mana yang dianggap benar, atau mungkin semua datanya benar, namun memiliki sudut pandang yang berbeda.

Setelah tringulasi dilakukan maka peneliti akan melakukan uji member check, tujuannya untuk mengetahui seberapa jauh data yang diperoleh sesuai dengan apa yang diberikan oleh pemberi data. Sugiyono (2012) menjelaskan member check adalah proses pengecekan data yang diperoleh peneliti kepada pemberi data. Apapbila data yang ditemukan disepakati olehh para pemberi data berarti datanya valid, sehingga semakin dipercaya, tetapi apabila data yang ditemukan peneliti dengan berbagai penafsirannya tidak disepakati oleh pemberi data, maka peneliti perlu melakukan diskusi dengan pemberi data, dan apabila perbedaannya tajam, maka peneliti harus merubah temuannya, dan harus menyesuaikan dengan apa yang diberi oleh pemberi data.

\section{HASIL DAN PEMBAHASAN}

Penerapan Iklim Organisasi

1. Struktur

Pada dimensi ini, dapat diukur apakah organisasi memiliki struktur tinggi atau struktur rendah.

-Struktur tinggi apabila anggota organisasi merasa pekerjaan mereka didefinisikan secara baik.

-Struktur rendah apabila mereka merasa tidak ada kejelasan mengenai siapa yang melakukan tugas dan mempunyai kewenangan dalam mengambil keputusan.

Pada dimensi ini, berdasarkan pengukuran terkait struktur tinggi dan rendah tersebut diatas, dapat dikatakan bahwa KSP Bina Sejahtera memiliki struktur tinggi, karena masing-masing informan mengetahui secara jelas apa yang menjadi jabatan serta tugas dan tanggung jawab mereka dalam koperasi.

2. Standar-Standar

Pada dimensi ini, dapat diukur apakah organisasi memiliki standar-standar tinggi atau standarstandar rendah.

-Standar-standar tinggi artinya anggota organisasi selalu berupaya mencari jalan untuk meningkatkan kinerja.

-Standar-standar rendah merefleksikan harapan yang lebih rendah untuk kinerja.

Karyawan KSP Bina Sejahtera menyatakan bahwa mereka selalu berusaha untuk melakukan usahausaha dan pembelajaran guna meningkatkan kinerja mereka dalam pekerjaan. Setiap informan memiliki masing-masing cara yang berbeda terkait usaha dan pembelajaran mereka, dan melakukan evaluasi untuk menilai kinerja yang mereka lakukan.

3. Tanggung Jawab

Pada dimensi ini, dapat diukur apakah organisasi memiliki tanggung jawab tinggi atau tanggung jawab rendah.

-Tanggung jawab tinggi menunjukkan bahwa anggota organisasi merasa didorong untuk menyelesaikan masalahnya sendiri.

-Tanggung jawab rendah menunjukkan bahwa pengambilan resiko dan percobaan terhadap pendekatan baru tidak diharapkan.

Pada dimensi ini, berdasarkan pengukuran terkait tanggung jawab tinggi dan rendah tersebut diatas, dapat dikatakan bahwa karyawan memiliki tingkat kesadaran akan tanggung jawab yang tinggi. 
Informan menyatakan bahwa apabila mereka sedang menghadapi kendala terkait pekerjaan mereka, mereka mempunyai inisiatif untuk dapat mencari solusi untuk mengangani kendala tersebut.

4. Penghargaan

Pada dimensi ini, penghargaan mengindikasikan bahwa anggota organisasi merasa dihargai jika mereka dapat menyelesaikan tugas secara baik. Penghargaan merupakan ukuran penghargaan dihadapkan dengan kritik dan hukuman atas penyelesaian pekerjaan. Setiap informan merasa puas saat mereka menerima pujian dan penghargaan atas kinerja mereka yang baik, namun mereka tidak mau terlena pada zona itu, melainkan mereka merasa semakin termotivasi untuk mencapai kinerja yang lebih baik lagi. Selain itu juga, setiap informan siap menerima kritikan yang diterima atas kinerja yang buruk ataupun teguran saat mereka melakukan kesalahan.

5. Dukungan

Pada dimensi ini, dapat diukur apakah organisasi memiliki dukungan tinggi atau dukungan rendah.

-Dukungan tinggi jika anggota organisasi merasa bahwa mereka bagian tim yang berfungsi dengan baik dan merasa memperoleh bantuan dari atasannya, jika mengalami kesulitan dalam menjalankan tugas.

-Dukungan rendah jika anggota organisasi merasa terisolasi atau tersisih sendiri.

Karyawan pada KSP Bina Sejahtera menganggap bahwa mereka adalah satu tim. Sehingga seperti yang dinyatakan informan, mereka menganggap setiap bagian dari tim memiliki bagian yang sama penting dalam koperasi. Mereka mendukung rekan sekerja mereka baik melalui pikiran maupun tindakan, terutama apabila ada rekan sekerja yang menghadapi kendala dalam pekerjaannya. Juga mereka menyatakan bahwa pimpinan memberikan mereka dukungan dalam bekerja, juga selalu menanyakan apa yang menjadi kendala dari setiap karyawan.

6. Komitmen

Pada dimensi ini, dapat diukur apakah organisasi memiliki komitmen kuat atau komitmen rendah. -Komitmen merefleksikan perasaan bangga anggota terhadap organisasinya dan derajat kesetiaan terhadap pencapaian tujuan organisasi. Perasaan komitmen kuat berisolasi dengan kesetiaan personal. -Level rendah komitmen artinya karyawan merasa apatis terhadap organisasi dan tujuannya.

Informan menyatakan bahwa mereka bangga sebagai anggota dari KSP Bina Sejahtera, mereka pun tidak malu untuk menyatakan bahwa mereka adalah karyawan KSP Bina Sejahtera diluar lingkungan kerja mereka. Alasannya karena mereka merasa sudah menerima lebih dari cukup dari koperasi, yang mana mereka merasa selama bekerja hak mereka dipenuhi sebagai karyawan, dan ada juga yang merasa bahwa sudah lama mereka bekerja pada koperasi ini dan sudah merasa sebagai satu keluarnya, jadi mereka bangga dengan koperasi dan tim kerja mereka. Informan juga menyatakan bahwa komitmen mereka untuk terus meningkatkan kinerja itu ada sejak awal mereka bekerja pada KSP Bina Sejahtera, juga dengan komitmen mereka untuk turut dalam evaluasi kinerja rutin yang dibuat oleh koperasi sebagai wadah sharing bagi setiap karyawan.

\section{Penerapan OCB}

\section{Altruism}

Perilaku karyawan dalam menolong rekan kerjanya yang mengalami kesulitan dalam situasi yang sedang dihadapi baik mengenai tugas dalam organisasi maupun masalah pribadi orang lain. Dimensi ini mengarah kepada memberi pertolongan yang bukan merupakan kewajiban yang ditanggungnya. Terkait dengan hal saling menolong, informan memberi pernyataan bahwa mereka tidak memiliki keraguan dalam melakukannya kepada rekan kerja yang membutuhkan pertolongan, baik pada waktu dan lingkup pekerjaan maupun diluar pekerjaan.

\section{Conscientiousness}

Conscientiousness mengacu pada sikap lebih berhati-hati dan mendengarkan kata hati. Individu yang mempunyai skor tinggi pada dimensi ini yaitu, memiliki kontrol diri yang bagus, terorganisir, memprioritaskan tugas, mengikuti norma dan peraturan. Terkait dengan dimensi conscientiousness ini, informan memberikan jawaban yang berbeda sesuai dengan jabatan serta tugas tanggung jawab mereka dalam koperasi. Berdasarkan jawaban yang informan berikan, dapat dilihat bahwa secara 
keseluruhan karyawan melakukan pengorganisasian tugas dengan cara dan tehnik yang berbeda sesuai dengan tugas tanggung jawab mereka.

\section{Sportmanship}

Individu dengan sikap sportmanship yang tinggi akan sangat memperhatikan hal-hal detail dalam pekerjaannya, dapat secara fair menjalankan pekerjaannya dan sedikit mengeluh, dan kemampuan beradaptasi yang tinggi dengan situasi dan lingkungan kerjanya. Karyawan yang memiliki sportmanship tinggi akan dengan mudah menerima kebijakan baru itu dan mengesampingkan masalah-masalah kecil yang mungkin muncul disebabkan oleh kebijakan baru tersebut.

4. Courtessy

Dimensi courtessy dapat digambarkan dengan sebuah bentuk tindakan yang bertujuan untuk mencegah munculnya masalah, sedangkan secara arti katta courtessy dapat diartikan dengan sikap sopan, dan mempertimbangkan orang lain. Courtessy terkait dengan tindakan sopan dan mempertimbangkan orang lain. Informan selalu menekankan bahwa mereka semua adalah satu tim dan satu keluarga, sehingga mereka selalu berhati-hati dalam melakuan tindakan, sehingga tidak akan merugikan rekan sekerja mereka.

\section{Civic Virtue}

Perilaku yang mengindikasikan tanggung jawab pada kehidupan organisasi (mengikuti perubahan dalam organisasi, mengambil inisiatif untuk merekomendasikan bagaimana operasi atau prosedurprosedur organisasi dapat diperbaiki, dan melindungi sumber-sumber yang dimiliki oleh organisasi). Informan mengungkapkan bahwa mereka cukup aktif memberi saran untuk perbaikan dalam evaluasi kinerja mingguan, yang bermuatan saling sharing antar karyawan juga termasuk pimpinan didalamnya terkait dengan kinerja selama satu minggu sebelumnya, dan juga saling sharing untuk peningkatan kinerja diminggu yang akan berjalan.

Beberapa faktor yang dapat mempengaruhi iklim organisasi, antara lain, faktor pertama adalah lingkungan ekternal. Sebuah organisasi yang sama pada umumnya memiliki iklim organisasi yang sama. KSP Bina Sejahtera merupakan sebuah koperasi yang berjalan berdasarkan azas kekeluargaan dan gotong royong, sama halnya dengan koperasi lain pada umumnya. Terkait dengan hal ini, para karyawan koperasi haruslah memiliki komunikasi yang baik dengan pimpinan maupun karyawan lainnya sebagai rekan sekerja. Sehingga setiap koperasi, demikian halnya juga dengan KSP Bina Sejahtera, berdasarkan azas tersebut, dapat ditemukan adanya komunikasi yang baik serta ikatan emosional dari para karyawan.

Faktor kedua dan ketiga yaitu strategi dan pengaturan organisasi. Berdasarkan pada jawaban informan, faktor yang mempengaruhi mereka adalah rasa tanggung jawab, merasa harus melakukan kewajiban karena haknya telah dipenuhi oleh organisasi, merasa perlunya kerja sama dan komunikasi yang baik, serta keinginan untuk menyelesaikan pekerjaan secara maksimal demi kemajuan organisasi dan diri sendiri. Hal ini menunjukkan bahwa para karyawan mengerti dengan benar akan tugas dan tanggung jawab pada jabatannya di organisasi, serta memiliki usaha untuk mencapai tujuan organisasi dengan menjalin komunikasi dan kerja sama yang baik dengan pimpinan dan karyawan lainnya.

Selain faktor diatas, terlihat juga dari hasil wawancara sebelumnya, bahwa pimpinan dari KSP Bina Sejahtera selalu berusaha memberi dukungan baik dengan cara memberi saran dan solusi apabila ada masalah, ataupun bertindak secara langsung untuk menanganinya. Selain itu juga, dari hasil observasi pada KSP Bina Sejahtera, terlihat bahwa hubungan yang terjalin antara pimpinan dengan karyawan terlihat akrab, namun karyawan tetap hormat kepada pimpinan. Selain itu juga pimpinan dan karyawan KSP Bina Sejahtera selalu melakukan evaluasi kerja untuk terus berusaha memperbaiki kinerja, serta mempertahankan bahkan meningkatkan pencapaian dari KSP Bina Sejahtera.

Tidak dipungkiri adanya hal-hal yang dapat menghambat dalam terciptanya iklim organisasi yang baik, seperti yang dikemukakan para informan, misalnya terjadi beda pendapat dan miss-komunikasi, adanya kendala yang tidak diduga pada saat hendak menaati aturan misalnya seperti karyawan ingin datang tepat waktu namun dalam cuaca yang buruk seperti hujan deras, namun hal-hal tersebut tidak berujung pada hasil yang buruk tanpa solusi. Para karyawan menganggap selalu ada jalan keluar dan 
solusi dalam setiap masalah, dan bahkan salah satu informan mengatakan bahwa hal-hal yang menghambat bukanlah suatu tantangan melainkan sebuah dorongan dalam bekerja.

Berdasarkan hasil wawancara sebelumnya terkait tentang sosok pemimpin, telah diketahui bahwa pimpinan dari KSP Bina Sejahtera adalah sosok yang supportive, yang selalu memberi dukungan dan selalu peduli dengan karyawannya. Tipe pemimpin yang menjadi faktor pemicu munculnya OCB adalah tipe pemimpin yang supportive yang dapat membuat karyawannya merasa diperhatikan kesejahteraannya, sehingga karyawan bersedia melakukan timbal balik kepada organisasi dan pimpinannya.

Selain itu pada faktor karakterstik tugas, diketahui bahwa karyawan memahami dengan benar tugas dan tanggung jawabnya dalam organisasi, serta hak dan wewenangnya, dan makna dari setiap tugas yang dikerjakan dan bagaimana tugas tersebut dapat saling mempengaruhi dan saling bergantung dengan tugas lainnya.

Faktor selanjutnya yang mempengaruhi OCB adalah karakteristik kelompok, dimana faktor ini dapat dilihat melalui kualitas hubungan antara anggota pada kelompok kerja, potensi atau kemampuan kelompok, serta dukungan tim yang dirasakan karyawan. Saat peneliti bertanya tentang faktor yang mendorong informan untuk melakukan tindakan OCB, jawaban yang diberikan informan adalah bahwa mereka merasa sudah seperti keluarga, karena mereka adalah rekan sekerja, dan karena itu mereka merasa wajib untung saling menolong, saling bekerja sama, saling mendukung, tanpa adanya imbalan, dan menurut mereka tidak ada alasan untuk tidak melakukan tindakan OCB. Selain itu juga mereka merasa tindakan OCB merupakan tindakan yang manusiawi, yang seharusnya semua orang lakukan dalam kerja tim.

Selain itu, faktor lainnya yaitu karakteristik organisasional yang dapat dilihat dari formalitas dalam organisasi, dukungan organisasi yang dipersepsikan karyawan, jarak antara karyawan dan pimpinan, serta hambatan-hambatan dalam organisasi, serta faktor lainnya yaitu konteks kultural yang dapat dilihat dari individualisme dan kolektivisme serta jarak kekuasaan. Hal ini ditunjukan pada KSP Bina Sejahtera, dengan adanya kerja sama tim yang baik adanya dukungan dari pimpinan kepada karyawan dan juga antar sesama karyawan, hubungan yang akrab antara pimpinan dengan karyawan serta karyawan dengan karyawan lainnya namun tetap patuh dann memiliki rasa hormat, serta hambatanhambatan yang selalu berusaha untuk dijadikan dorongan dalam bekerja, dengan selalu bersama-sama mencari solusi untuk menyelesaikan masalah yang ditemui dalam organisasi.

Berdasarkan pernyataan informan, faktor yang menghambat mereka untuk melakuakan tindakan OCB, hanyalah pada saat ada rekan yang butuh pertolongan, namun mereka berada di kondisi yang tidak memungkinkan untuk menolong, seperti saat ada teman yang membutuhkan sesuatu atau sedang ada dalam kesulitan keuangan, pada saat mereka tidak bisa menolong, mereka cenderung untuk meminta maaf dan menawarkan hal lain yang mungkin bisa mereka lakukan untuk meringankan masalah rekan tersebut.

\section{PENUTUP \\ Kesimpulan}

Berdasarkan hasil penelitian yang telah dilakukan pada KSP Bina Sejahtera, peneliti menyimpulkan bahwa iklim organisasi yang baik dan adanya penerapan Organizational Citizenship Behavior (OCB) sangatlah penting bagi kemajuan sebuah organisasi karena memiliki pengaruh terhadap peningkatan kinerja yang maksimal. Selain itu, iklim organisasi mempengaruhi terciptanya tindakan OCB yang dilakukan oleh karyawan, karena iklim organisasi merupakan kondisi awal yang memicu terjadinya OCB. Ketika iklim organisasi baik maka anggota organisasi akan selalu mendukung pekerjaan melebihi kewajiban seharusnya dan akan selalu mendukung tujuan organisasi.

Tindakan OCB tercipta karena adanya komunikasi dan kerja sama yang baik serta lingkungan kerja yang kondusif yang menjadikan anggota organisasi memiliki ikatan emosional sehingga tidak enggan untuk melakukan tindakan OCB, merasakan hal itu sebagai kewajiban dan keharusan sebagai manusia dan rekan kerja yang sudah seperti keluarga, dan tidak ada alasan bagi mereka untuk tidak melakukan tindakan OCB. Karyawan KSP Bina Sejahtera juga merasa bahwa iklim organisasi dan OCB 
merupakan hal yang penting dan sangat perlu untuk diterapkan di setiap organisasi, karena dengan iklim organisasi akan meningkatkan kinerja tim jauh lebih baik.

Selain dari pandangan karyawan terhadap iklim organisasi dan OCB pada KSP Bina Sejahtera, peneliti juga melakukan wawancara dengan nasabah dan meminta data jumlah nasabah dan pendapatan. Berdasarkan wawancara nasabah, tentang alasan mengapa mereka memilih KSP Bina Sejahtera, disimpulkan bahwa mereka memilih koperasi ini karna administrasi yang mudah, cepat, dan tepat, bunga yang rendah, serta pelayanan yang ramah, sopan, dan cepat. Selaras dengan hasil wawancara ini, data yang diperoleh dari KSP Bina Sejahtera, terlihat bahwa tejadi peningkatan baik dari jumlah nasabah maupun jumlah pendapat secara berkala dalam kurun lima tahun terakhir.

\section{Saran}

Berdasarkan hasil penelitiaan ini, diharapkan agar pimpinan serta karyawan KSP Bina Sejahtera terus mempertahankan iklim organisasi yang baik dalam koperasi ini, sehingga koperasi yang sekarang tetap terus bertahan dan meningkat demi keberhasilan organisasi maupun anggota organisasi dan tanpa terkecuali juga para nasabahnya. Menjaga kerja sama tim yang baik dan terus menerus melakukan evaluasi kerja untuk keberhasilan organisasi, sehingga KSP Bina Sejahtera juga bisa menjadi contoh bagi koperasi lain yang belum mengenal dan mengetahui pentingnya iklim organisasi dan penerapan tindakan OCB untuk menunjang keberhasilan organisasi.

Selain itu juga, dengan kendala-kendala yang dihadapi oleh tiap karyawan, seperti terkadang sulit untuk menyediakan waktu untuk melakukan sharing dengan pimpinan ataupun karyawan lain, peneliti mengharapkan karyawan memanfaatkan waktu dengan baik untuk melakukan sharing pada saat dilakukan rapat evaluasi mingguan, juga aktif dalam menyampaikan saran dan pendapat dalam rapat tersebut, serta mengorganisir terlebih dahulu setiap pekerjaan yang dilakukan, agar kiranya dapat mengelola waktu dengan baik. Dan juga kendala karyawan pada bagian AO mengenai nasabah yang sering menunggak atau pindah kota, peneliti mengharapkan karyawan bagian AO semakin aktif dalam menemui atau mencari nasabah tersebut, serta saling berbagi tugas dalam satu tim kerja pada bagian AO agar lebih efektif dalam penyelesaiannya.

\section{REFERENSI}

Adi, Muhammad, 2011. Hubungan Antara Organizational Citizenship Behavior (OCB) dengan Kepuasan Kerja pada Karyawan PT. Surya Karang Indah Surabaya, Undergraduate Thesis, Fakultas Dakwah Institut Agama Islam Negeri Sunan Ampel, Surabaya.

Ahdiyana, Marita, 2010. "Dimensi Organizational Citizenship Behavior (OCB) dalam Kinerja Organisasi”. Jurnal Efisiensi, Vol.X, No.1, Februari 2010:10-19.

Ariansyah dan Kusumaputri, 2013. "Iklim Organisasi dan Kualitas Kehidupan Kinerja Karyawan". Jurnal Humanitas, Vol. X, No.1, Januari 2013:75-86.

Bangkit, 2010. Hubungan antara Komitmen Organisasi dan Intensi Turnover dengan Organizational Citizenship Behavior pada Karyawan PT Lotte Shopping Indonesia, Skripsi Psikologi, Fakultas Kedokteran Universitas Sebelas Maret, Surakarta.

Binus University Quality Management Center, “In-Depth Interview (Wawancara Mendalam)”, 28 Oktober 2014, https://qmc.binus.ac.id/2014/10/28/in-depth-interview-wawancara-mendalam/ (diakses oleh peneliti tanggal 10 November 2017).

Davis and Newstrom, 2002. Organizational Behavior : Human Behavior at Work. $11^{\text {th }}$ Edition. McGraw-Hill Companies. New York.

Karundeng, Christine, 2013. "Pengaruh Iklim Organisasi Terhadap Kinerja Karyawan pada PT. Taspen (Persero) Cabang Manado. E-Journal Unsrat, 1-15. 
Kusumajati, Dian, 2014 “Organizational Citizanship Behavior (OCB) Karyawan pada Perusahaan”. Jurnal Humaniora, Vol.5, No.1, April 2014:62-70.

Novliadi, Ferry, 2006. "Organizational Citizenship Behavior Karyawan Ditinjau dari Persepsi terhadap Kualitas Interaksi Atasan-Bawahan dan Persepsi terhadap Dukungan Organisasional”. Jurnal Psikologia, Vol. 2, No.1, Juni 2006:39-46.

Pandelaki, Imanuel, 2016. "Motif yang Mendasari Pegawai Menerapkan Organizational Citizenship Behavior pada Perusahaan Haermony Meubel. Jurnal Manajemen dan Start-Up Bisnis, Vol.1, No.5, Desember 2016:529-535.

Prihatsanti dan Dewi, 2010. "Hubungan Antara Iklim Organisasi dan Organizational Citizenship Behavior (OCB) pada Guru SD Negeri di Kecamatan Mojolaban Sukoharjo". Jurnal Psikologi Undip, Vol.7, No.1, April 2010:11-17.

Robbins, Stephen, 1990. Organization Theory : Structure Designs and Applications. Third Edition. Prentice Hall. New Jersey.

Robbins, Stephen, 2006. Perilaku Organisasi. Edisi Kesepuluh. Jakarta: PT INDEKS Kelompok Gramedia.

Sambung, Roby, 2014. "Pengaruh Kepribadian Terhadap Organizational Citizenship Behavior (OCB) dan Komitmen Organisasional Sebagai Intervening (Studi pada Universitas Palangka Raya) “. Jurnal Manajemen dan Akuntansi, Vol.3, No.1, April 2014:1-16.

Satwika dan Himam, 2014. "Kinerja Karyawan Berdasarkan Keterbukaan Terhadap Pengalaman, Organizational Citizenship Behavior dan Budaya Organisasi”. Jurnal Psikologi, Vol.41, No.2, Desember 2014:205-217.

Sugiyono, 2012. Memahami Penelitian Kualitatif. Bandung: CV. Alfabeta.

Teori Online, "Organizational Citizenship Behavior-OCB", 1 Februari 2010, https://teorionline.wordpress.com/2010/02/01/organizational-citizenship-behavior-ocb/ (diakses oleh peneliti tanggal 10 November 2017).

Teori-Teori Manajemen dan Organisasi, "Iklim Organisasi”, 11 Desember 2015, https://theorymanajemendanorganisasi.blogspot.co.id/2015/12/iklim-organisasi.html (diakses oleh peneliti tanggal 10 November 2017).

Utami, Paranoan, dan Riady, 2013. "Pengaruh Iklim Organisasi Terhadap Prestasi Kerja Pegawai Dinas Perindustrian Perdagangan Kota Samarinda". E-Journal Administrative Reform Unmul, Vol.1, No.2, 2013:356-369.

Wahyudi, Adly, 2016. Hubungan Antara Motivasi Kerja Intrinsik dan Kepuasan Kerja dengan Organizational Citizenship Behavior pada Karyawan PT. Joglosemar Surakarta, Skripsi Psikologi, Fakultas Kedokteran Universitas Sebelas Maret, Surakarta.

Wirawan, 2007. Budaya dan Iklim Organisasi, Jakarta: Salemba Empat.

Yuniar, Nurtjahjanti, dan Rusmawati, 2011. "Hubungan Antara Kepuasan Kerja dan Resiliensi dengan Organizational Citizenship Behavior (OCB) pada Karyawan Kantor Pusat PT. BPD Bali". Jurnal Psikologi Undip, Vol.9, No.1, April 2011:11-20. 